\title{
In Vitro Bactericidal and Virucidal Efficacy of Povidone-Iodine Gargle/Mouthwash Against Respiratory and Oral Tract Pathogens
}

\author{
Maren Eggers - Torsten Koburger-Janssen • Markus Eickmann • \\ Juergen Zorn
}

Received: February 13, 2018 / Published online: April 9, 2018

(C) The Author(s) 2018

\section{ABSTRACT}

Introduction: Recent virus epidemics and rising antibiotic resistance highlight the importance of hygiene measures to prevent and control outbreaks. We investigated the in vitro bactericidal and virucidal efficacy of povidoneiodine (PVP-I) 7\% gargle/mouthwash at defined dilution against oral and respiratory tract pathogens.

Methods: PVP-I was tested against Klebsiella pneumoniae and Streptococcus pneumoniae according to bactericidal quantitative suspension test EN13727 and against severe acute respiratory syndrome and Middle East respiratory syndrome coronaviruses (SARS-CoV and MERS$\mathrm{CoV})$, rotavirus strain $\mathrm{Wa}$ and influenza virus $\mathrm{A}$

Enhanced digital features To view enhanced digital features for this article, go to https://doi.org/10.6084/ m9.figshare.6027224.

\section{Eggers ( ()}

Labor Prof. Gisela Enders MVZ GbR, Stuttgart, Germany

e-mail: eggers@labor-enders.de

T. Koburger-Janssen

Hygiene Nord GmbH, Greifswald, Germany

M. Eickmann

Institute for Virology, Philipps University of

Marburg, Marburg, Germany

J. Zorn

Mundipharma Research GmbH \& Co.KG, Limburg,

Germany subtype H1N1 according to virucidal quantitative suspension test EN14476. PVP-I 7\% gargle/mouthwash was diluted 1:30 with water to a concentration of $0.23 \%$ (the recommended concentration for "real-life" use in Japan) and tested at room temperature under clean conditions $[0.3 \mathrm{~g} / \mathrm{l}$ bovine serum albumin (BSA), viruses only] and dirty conditions $(3.0 \mathrm{~g} / \mathrm{l}$ $\mathrm{BSA}+3.0 \mathrm{ml} / \mathrm{l}$ erythrocytes) as an interfering substance for defined contact times (minimum $15 \mathrm{~s}$ ). Rotavirus was tested without protein load. $A \geq 5 \log _{10}(99.999 \%)$ decrease of bacteria and $\geq 4 \log _{10}(99.99 \%)$ reduction in viral titre represented effective bactericidal and virucidal activity, respectively, per European standards.

Results: PVP-I gargle/mouthwash diluted 1:30 (equivalent to a concentration of $0.23 \%$ PVP-I) showed effective bactericidal activity against Klebsiella pneumoniae and Streptococcus pneumoniae and rapidly inactivated SARS-CoV, MERS$\mathrm{CoV}$, influenza virus A (H1N1) and rotavirus after $15 \mathrm{~s}$ of exposure.

Conclusion: PVP-I $\quad 7 \%$ gargle/mouthwash showed rapid bactericidal activity and virucidal efficacy in vitro at a concentration of $0.23 \%$ PVP-I and may provide a protective oropharyngeal hygiene measure for individuals at high risk of exposure to oral and respiratory pathogens.

Funding: Mundipharma Research $\mathrm{GmbH} \& \mathrm{Co}$. KG (MRG). 
Keywords: Anti-infective agents; Local; Microbial sensitivity tests; Mouthwashes; Povidone-iodine; Respiratory tract infections

\section{INTRODUCTION}

Antibiotic resistance is rising to dangerously high levels worldwide [1]. Oral and respiratory tract infections caused by bacteria such as Streptococcus pneumoniae and Klebsiella pneumoniae pose a particular threat because of the rise of antibiotic-resistant strains, with vulnerable patient populations at high risk of infection $[2,3]$. Seasonal endemic viruses such as influenza are another significant cause of respiratory infection; worldwide, annual influenza epidemics are estimated to result in about 3-5 million cases of severe illness and about 250,000-500,000 deaths [4]. In addition to seasonal endemic viruses, emerging and re-emerging virus outbreaks such as severe acute respiratory syndrome and Middle East respiratory syndrome coronaviruses (SARS-CoV and MERS-CoV) require close contact for human-tohuman transmission and can spread nosocomially $[5,6]$. Unlike the remaining four coronaviruses, which are typically associated with mild, self-limiting respiratory illness, SARS-CoV and MERS-CoV cause severe respiratory symptoms and are associated with considerable mortality [7]. There is no vaccination or any specific antiviral treatment available for SARS$\mathrm{CoV}$ and MERS-CoV. Outbreaks can, however, be quickly and effectively controlled with preventive strategies based upon early accurate viral diagnosis, knowledge of the current epidemiological season and effective hygiene practices to decrease the risk of transmission [8].

Effective hand hygiene minimises transmission of pathogens from contaminated hands of an infected individual through either direct person-to-person contact or indirectly via contamination of surfaces $[9,10]$. Respiratory pathogens such as influenza are also transmitted via airborne dispersion of small particle aerosols $(\leq 5 \mu \mathrm{m})$ when an infected individual breathes, coughs or sneezes [11], while respiratory syncytial viruses, SARS-CoV and MERS-CoV can be spread by large droplets propelled through the air and inoculated into the eyes, nose and mouth at close range [12]. Considering these modes of transmission, oral hygiene by gargling, together with hand washing and mask use [13], may be beneficial to help minimise the risk of both community- and hospitalacquired respiratory infections. Gargling is also deemed to bring about favourable effects through removal of oral/pharyngeal protease that helps viral replication [14]. Effectiveness of the antiseptic agent in killing pathogens is paramount in selecting gargles/mouthwashes for protective hygiene and can be achieved by ensuring that antiseptic agents pass a standard bactericidal or virucidal activity test. A rapid action is also desirable, as the length of time that individuals are willing or able to keep the product in the oral cavity is limited.

Povidone-iodine (PVP-I) is a broad-spectrum antimicrobial that has been used in infection control and prevention for over 60 years [15] and is available in various preparations for use as a disinfectant for the skin, hands and mucosal surfaces, as well as for wound treatment and eye applications. PVP-I has well-established general antimicrobial activity, demonstrating in vitro efficacy against gram-positive, gramnegative and some spore-forming bacteria (clostridia, Bacillus spp.) and mycobacteria [16-20] and a wide range of enveloped and nonenveloped viruses [21-23]. Recent in vitro studies have demonstrated rapid virucidal activity of PVP-I products against Ebola virus, MERS-CoV and European reference enveloped virus [modified vaccinia virus Ankara (MVA)] $[24,25]$. Considering the proven in vitro efficacy, gargling with PVP-I may be an effective method of preventing the spread of respiratory viruses when an individual is contaminated by the airborne/droplet route or after uptake via the mouth (such as when touching the mouth or food with contaminated hands). The benefit of gargling with PVP-I has already been noted in Japanese clinical respiratory guidelines [26].

This study investigated the in vitro bactericidal and virucidal efficacy of PVP-I 7\% gargle/mouthwash against relevant oral and respiratory tract pathogens based on the European standards EN13727 [27] and EN14476 [28]. 


\section{METHODS}

Antiseptic product performance against test bacteria was performed according to bactericidal quantitative suspension test EN13727:2012 + A2:2015 [27] and against model viruses under defined test conditions, including temperature, contact time and interfering substances, according to virucidal quantitative suspension test EN14476:2013/ FprA1:2015 [28]. Testing was performed from 11 February 2016 to 8 March 2016. This article does not contain any studies with human participants or animals performed by any of the authors.

\section{Product Tested}

The antiseptic product tested was 7\% PVP-I gargle/mouthwash [brand-name Isodine, manufactured by Fukuchi Pharmaceutical Co., Ltd., Japan (bactericidal testing) and Mundipharma Pharmaceuticals Ltd. (virucidal testing)]. The 7\% PVPI solution was diluted with water $(2 \mathrm{ml} \rightarrow 60 \mathrm{ml}$, equivalent to a concentration of $0.23 \%$ of the active ingredient) prior to testing, according to the manufacturer's instructions for use in Japan [29]. When using cell cultures in antiseptic product testing, the target cells are often more sensitive to the active ingredient. To overcome this, the test product was further tested at 1:10, 1:100 and 1:1000 dilutions of the $7 \%$ solution in bactericidal testing (corresponding to concentrations of $0.7 \%, 0.07 \%$ and $0.007 \%$ of PVP-I) and at $1: 300$ and 1:3000 dilutions in virucidal testing (corresponding to concentrations of $0.023 \%$ and $0.0023 \%$ of PVP-I).

\section{Bactericidal Testing}

Both gram-positive (Streptococcus pneumoniae, DSM 24048, ATCC 49619) and gram-negative (Klebsiella pneumoniae, DSM 16609) reference strains were tested.

Inactivation tests were conducted once in accordance with EN13727:2012 + A2:2015 [27] at $20.0 \pm 1.0^{\circ} \mathrm{C}$. A suspension of test organisms was added to the product test solution under dirty conditions $[3.0 \mathrm{~g} / \mathrm{l}$ bovine serum albumin
(BSA) $+3.0 \mathrm{ml} / \mathrm{l}$ erythrocytes] as interfering substance. After the specified contact time (15 and $30 \mathrm{~s}$ ), a 1-ml aliquot was taken, and the bactericidal activity in this portion was immediately neutralised with $3 \%$ Tween $80+0.1 \%$ histidine + $0.3 \%$ lecithin $+0.5 \%$ sodium thiosulphate. For each test suspension, two 1-ml samples were spread on at least two plates each. The number of surviving test organisms in the mixture was calculated for each sample and the reduction factor (RF) determined with respect to the corresponding test suspension. A reduction of bacteria of $\geq 5 \log _{10}$ ( $\geq 99.999 \%$ ) compared with the control was considered to represent effective antibacterial efficacy according to European standards.

\section{Virucidal Testing}

The test viruses were coronaviruses SARS (strain Frankfurt) and MERS (HCoV-EMC/2012), influenza A virus (H1N1)pdm09 and non-enveloped human rotavirus strain $\mathrm{Wa}$. The host cells used for the virus cultivation and suspension test were Vero E6 cells for SARS-CoV and MERSCoV, Madin-Darby Canine Kidney (MDCK) cells for influenza virus A subtype H1N1 and MA104 cells for human rotavirus strain Wa.

Inactivation tests were conducted once in accordance with EN14476:2013/FprA1:2015 [28] at $20.0 \pm 1.0^{\circ} \mathrm{C}$. The virus suspension was added to the product test solution under clean $(0.3 \mathrm{~g} / \mathrm{l}$ BSA $)$ and dirty conditions $(3.0 \mathrm{~g} / \mathrm{l}$ $\mathrm{BSA}+3.0 \mathrm{ml} / \mathrm{l}$ erythrocytes) as interfering substance, except for the rotavirus suspension, which was tested without protein load (using distilled water as the interfering substance). The test assay comprised $100 \mu \mathrm{l}$ virus suspension, $100 \mu \mathrm{l}$ interfering substance and $800 \mu \mathrm{l}$ PVP-I product (at the defined dilutions). A virus control mixture was also assessed using distilled water in place of the test product. After the specified contact time (15 s for SARS-CoV and MERS-CoV, 15 and $30 \mathrm{~s}$ for influenza, and 15, 30,60 and $120 \mathrm{~s}$ for rotavirus), virucidal activity of the solution was immediately suppressed by dilution with nine volumes of ice-cold medium $(\mathrm{MEM}+2.0 \% \mathrm{FCS})$ and serially diluted ten fold. Due to the immediate titration, no after-effect of the test product could occur. For each test 
suspension, six wells ( 5 wells for SARS-CoV and MERS-CoV) of a microtitre plate containing a confluent monolayer of host cells were inoculated with $100 \mu \mathrm{l}$ of test suspension, and the cells were incubated at $37.0^{\circ} \mathrm{C}$ in a humidified atmosphere under $5.0 \% \mathrm{CO}_{2}$.

After incubation, the medium was removed. For staining of influenza virus or rotavirus infectivity, cells were fixed for $10 \mathrm{~min}$ with ice-cold acetone/methanol (40:60) and then blocked with $1 \%$ BSA in phosphate-buffered saline (PBS) for $30 \mathrm{~min}$ and stained by the immunoperoxidase method. For testing against influenza A, a monoclonal antibody (25 $\mu \mathrm{l} /$ well) (Chemicon, Temecula, CA) against influenza A (MAB8251) was applied. After incubation for $30 \mathrm{~min}$ at $37^{\circ} \mathrm{C}$, the plates were washed and incubated with secondary horseradish peroxidase-labelled anti-mouse antibody (anti-mouse-HRP, DakoCytomation, Germany) and finally with 3-amino-9-ethylcarbazole (AEC) substrate (Sigma, St. Louis, MO, USA). For testing against rotavirus, a peroxidase-labeled polyclonal goat antibody (BT81-2998-04, Biotrend, Köln, Germany) against human rotavirus was applied. After incubation for $30 \mathrm{~min}$ at $37^{\circ} \mathrm{C}$, the plates were washed and incubated with secondary horseradish peroxidase-labelled anti-goat antibody (Sigma-Aldrich, Germany) at a dilution of 1:500 and finally with AEC substrate. For all virus testing, AEC (dilution 1:500) was used to visualise antibody binding and infected cells were stained red. Stained cells were examined with a light microscope. The cells were examined microscopically for cytopathic effects (CPE). SARS or MERS infected cells were not stained, but examined microscopically for infectivity and cytopathic effects.

The virus titres were determined using the Spearman-Kärber method [30, 31] and expressed as tissue culture infectious dose 50\% $\left(\mathrm{TCID}_{50} / \mathrm{ml}\right)$. The virucidal activity was determined by the difference of the logarithmic titre of the virus control minus the logarithmic titre of the test virus $\left(\Delta \log _{10} \mathrm{TCID}_{50} / \mathrm{ml}\right)$. This difference was given as an RF including its 95\% confidence interval. A reduction in virus titre of $\geq 4 \log _{10}$ (corresponding to an inactivation of $\geq 99.99 \%$ ) was regarded as evidence of sufficient virucidal activity. The calculation was performed according to EN14476 [28].

\section{RESULTS}

\section{Bactericidal Activity}

The $\log _{10}$ reduction factors produced by PVP-I $7 \%$ gargle/mouthwash at defined dilutions against Klebsiella pneumoniae and Streptococcus pneumoniae under dirty conditions are shown by contact time in Table 1. Bacterial counts in the control samples were $7.61 \log _{10} / \mathrm{ml}$ for Klebsiella pneumoniae and $7.34 \log _{10} / \mathrm{ml}$ for Streptococcus pneumoniae. All bacterial counts were reduced by between $>5.20$ and $>5.47 \log _{10} / \mathrm{ml}$ (corresponding to a reduction in bacterial count of $\geq 99.999 \%$ ) after $15 \mathrm{~s}$ of contact time at PVP-I concentrations of $0.7 \%$ (1:10 dilution) and $0.23 \%$ ( $1: 30$, i.e., recommended dilution). The lower concentrations of $0.07 \%$ and $0.007 \%$ did not reach the threshold reduction, except for the $0.07 \%$ solution against Streptococcus pneumoniae after $30 \mathrm{~s}$.

\section{Virucidal Activity}

The $\log _{10}$ reduction factors produced by PVP-I $7 \%$ gargle/mouthwash at defined dilutions against each test virus are shown by interfering substance and contact time in Table 2 . The viral titres present in the control samples under clean and dirty conditions, respectively, were 7.10 and $6.90 \log _{10} \mathrm{TCID}_{50} / \mathrm{ml}$ for SARS-CoV, 6.90 and $7.10 \log _{10} \mathrm{TCID}_{50} / \mathrm{ml}$ for MERS-CoV, 7.17 and $7.50 \log _{10} \mathrm{TCID}_{50} / \mathrm{ml}$ for influenza virus $\mathrm{A}$ subtype $\mathrm{H} 1 \mathrm{~N} 1$ and $6.17 \log _{10} \mathrm{TCID}_{50} / \mathrm{ml}$ for rotavirus (under clean conditions). All viral titres were reduced by between 4.40 and $6.00 \log _{10} \quad \mathrm{TCID}_{50} / \mathrm{ml}$ (corresponding to a reduction in viral titre of $\geq 99.99 \%$ for all viruses tested) after $15 \mathrm{~s}$ of contact time with PVP-I gargle at a concentration of $0.23 \%$ (1:30, i.e., recommended dilution). The lower PVP-I concentrations of $0.023 \%$ (1:300 dilution) and $0.0023 \%$ (1:3000 dilution) that were tested against rotavirus and influenza did not reach a $\log _{10}$ reduction in viral titre $\geq 4$, except for the $0.023 \%$ concentration against influenza under clean conditions. 
Table 1 Bactericidal activity of povidone-iodine 7\% oral solution against gram-positive and -negative bacteria under dirty conditions

\begin{tabular}{llll}
\hline Bacteria & Povidone-iodine concentration (\%) & \multicolumn{2}{l}{$\mathbf{L o g}_{\mathbf{1 0}}$ reduction factor } \\
\cline { 3 - 4 } & & $\mathbf{1 5} \mathbf{s}$ & $\mathbf{3 0 ~ s}$ \\
\hline Klebsiella pneumoniae & 0.7 & $>\mathbf{5 . 4 7}$ & $>\mathbf{5 . 4 7}$ \\
& 0.23 & $\mathbf{5 . 3 5}$ & $>\mathbf{5 . 4 7}$ \\
& 0.07 & $<2.79$ & 3.24 \\
Streptococcus pneumoniae & 0.007 & $<2.79$ & $<2.79$ \\
& 0.7 & $>\mathbf{5 . 2 0}$ & $>\mathbf{5 . 2 0}$ \\
& 0.23 & $>\mathbf{5 . 2 0}$ & $>\mathbf{5 . 2 0}$ \\
& 0.07 & 4.86 & $>\mathbf{5 . 2 0}$ \\
& 0.007 & $<2.52$ & $<2.52$ \\
\hline
\end{tabular}

Results shown in bold indicate bactericidal activity $\left(\geq 5 \log _{10}\right.$ reduction factor compared with control)

Dirty conditions: $3.0 \mathrm{~g} / \mathrm{l}$ bovine serum albumin $+3.0 \mathrm{ml} / \mathrm{l}$ erythrocytes

\section{DISCUSSION}

Oral and respiratory tract pathogens represent a significant threat to human health. Nosocomial infections are widespread, especially among more vulnerable patients, and are important contributors to morbidity and mortality. A growing number of bacterial infections are becoming harder, and sometimes impossible, to treat as antibiotics become less effective, and vaccination against respiratory viruses either does not exist or has incomplete coverage. When there is an emerging infectious disease outbreak, practicing appropriate hygiene is recommended for both healthcare workers and individuals to limit the spread of infection by breaking the transmission. Oral hygiene could further improve the success rate of hygiene measures, especially against respiratory pathogens.

The data from this in vitro study demonstrated rapid bactericidal and virucidal activity of PVP-I gargle/mouthwash against all respiratory pathogens tested according to European standard requirements. The minimum 15-s contact time proved to be sufficient for PVP-I $7 \%$ gargle/mouthwash to be effective at the recommended dilution in Japan of 1:30 (equivalent to a concentration of $0.23 \%$ of the active ingredient). PVP-I solution has shown similar rapid antimicrobial activity in previous in vitro studies. Against bacteria, Shimizu et al. demonstrated complete efficacy of PVP-I 0.2\% solution against clinical isolates of Klebsiella pneumoniae, Serratia marcescens, Pseudomonas aeruginosa, Alcaligenes faecalis and Alcaligenes xylosoxydans within $30 \mathrm{~s}$ using a simple methodology (the broth turbidity method) [18]. In another study, low concentrations of PVP-I gargle/mouthwash (0.23-0.47\%) killed methicillin-resistant Staphylococcus aureus (MRSA) and Pseudomonas aeruginosa, including multidrugresistant strains, within $15-60 \mathrm{~s}$ in the presence of oral organic matter from healthy volunteers, while $0.02 \%$ benzethonium chloride (BEC) and $0.002 \%$ chlorhexidine gluconate (CHG) were ineffective [32]. In a study comparing the bactericidal activities of three gargle/mouthwashes against isolate and standard strains of grampositive (MRSA) and -negative bacteria (Pseudomonas aeruginosa and Klebsiella pneumoniae), PVP-I (diluted 15-, 30- and 60-fold) elicited rapid killing of all three strains after $30 \mathrm{~s}$ of exposure, while cetylpyridinium chloride (CPC) was effective only against gram-negative strains after $60 \mathrm{~s}$ of exposure, and CHG was ineffective [33].

In previous virucidal studies, PVP-I gargle was found to inactivate a panel of viruses 


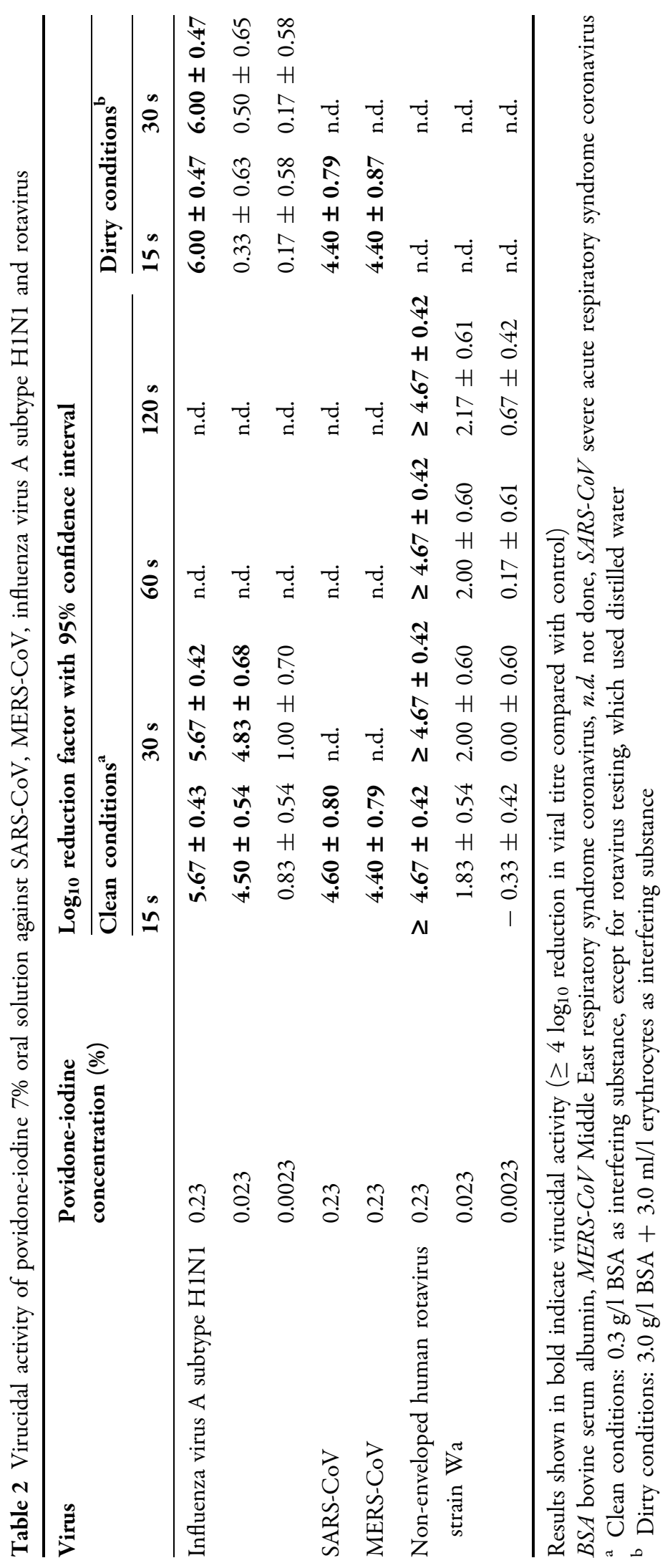


including adenovirus, mumps, rotavirus, poliovirus (types 1 and 3), coxsackie virus, rhinovirus, herpes simplex virus, rubella, measles, influenza and human immunodeficiency virus, while CHG, benzalkonium chloride (BAC), BEC and alkyldiaminoethyl-glycine hydrochloride (AEG) gargles were ineffective against adenovirus, poliovirus and rhinovirus [22]. Eggers et al. demonstrated the virucidal activity of PVP-I 4\% skin cleanser, $7.5 \%$ surgical scrub, $10 \%$ solution and $3.2 \%$ PVP-I/alcohol solution against Ebola virus and MVA and of PVP-I 7.5\% surgical scrub, $4 \%$ skin cleanser and 1\% gargle/mouthwash against MERS-CoV and MVA within $15 \mathrm{~s}$ of application $[24,25]$. Application of PVP-I products with concentrations of $0.23-1 \%$ for $1-2 \mathrm{~min}$ reduced SARS-CoV virus infectivity from $1.17 \times 10^{6} \mathrm{TCID}_{50} / \mathrm{ml}$ to below detectable levels in a study by Kariwa et al., although shorter contact times were not investigated [23]. Ito et al. reported a reduction in viral infectious titres of avian influenza $\mathrm{A}$ viruses (H5N1, H5N3, H7N7 and H9N2) to below detectable limits by incubation for only $10 \mathrm{~s}$ with six different PVP-I products including $0.23 \%$ gargle and $0.23 \%$ throat spray [34]. The anti-influenza activity of PVP-I involves inhibition of viral haemagglutinin binding activity and viral neuraminidase catalytic hydrolysis [35]. In the present study, PVP-I oral solution at a concentration of $0.23 \%$ was also effective against non-enveloped rotavirus without interfering substance after $15 \mathrm{~s}$ of exposure, which is in contrast to in vitro work by Steinmann et al. [36], in which 7.5\% PVP-I handwash was not active against the non-enveloped viruses tested, and by Sauerbrei and Wutzler [37], in which PVP-I took $5 \mathrm{~min}$ to inactivate polyomavirus SV40 and adenovirus.

In this study, the virucidal and bactericidal activity of PVP-I gargle/mouthwash was evaluated within a short exposure time (15s) to reflect a similar or shorter time than the actual gargling time in real-life conditions, since the length of time that individuals are willing to keep an antiseptic product in the oral cavity is limited. PVP-I oral solution at a concentration of $0.23 \%$ was effective against all pathogens tested in this study after the minimum contact time of $15 \mathrm{~s}$, regardless of protein load (except rotavirus, which was tested without protein load). Pathogens are eradicated by the active moiety (non PVP-bound 'free' iodine) being released into solution from the PVP-I complex, penetrating the cell wall and inactivating cells by forming complexes with amino acids and unsaturated fatty acids, resulting in impaired protein synthesis and alteration of cell membranes [38]. This basic mechanism of action leads to strong microbicidal activity expressed by multiple modes of action that include the disruption of microbial metabolic pathways, as well as destabilisation of the structural components of cell membranes, causing irreversible damage to the pathogen [39].

The results of this study suggest that the use of PVP-I gargle/mouthwash may be a useful protective measure against oral and respiratory tract infections. Indeed, following the H1N1 swine flu outbreak in 2009, Japan's Ministry of Health, Labour and Welfare recommended daily gargling as a protective hygiene measure to prevent upper respiratory tract infections (URTIs) [40], a practice supported by findings from studies that examined the role of gargling in both healthy individuals and those with frequent or persistent URTIs [14, 41, 42]. Limited clinical studies have been performed that used PVP-I gargle/mouthwash to reduce the incidence of respiratory infections in different settings. Shiraishi and Nakagawa showed a mean reduction rate in bacterial count immediately after gargling of 99.4\% for PVP-I in volunteers (compared with $59.7 \%$ for $\mathrm{CHG}$ and $97.0 \%$ for $\mathrm{CPC}$ ) and a significantly lower absence rate due to URTIs at a Japanese middle school where the use of PVP-I gargle was encouraged compared with schools where PVP-I gargle was not used [33]. In patients with chronic respiratory diseases, gargling with PVP-I was found to reduce the episodes of infections with Pseudomonas aeruginosa, Staphylococcus aureus (including MRSA) and Haemophilus influenzae by half [41]. Studies of prophylactic use of PVP-I gargle in patients requiring intubation have also shown significant reductions in oropharyngeal bacterial counts [43]. Oral hygiene using PVP-I may be of particular benefit in certain patient groups such as immunocompromised patients at risk of prolonged virus shedding (which can increase the potential for 
resistance to antiviral drugs and for nosocomial transmission), patients with influenza to reduce the risk of secondary bacterial infection (that may appear, e.g., as otitis media in children and thus avoid the need for antibiotics) and possibly in hospitalised patients to prevent the spread of influenza during high season.

The safety profile of PVP-I is well established. In contrast to other antiseptic agents, PVP-I oral care products do not lead to any irritation or damage of the oral mucosa, even with prolonged use [44, 45]. Although measurable systemic iodine absorption may occur with the long-term use of PVP-I, its clinical manifestation as thyroid dysfunction is not very common [39].

A limitation of this work is that the clinical relevance of such in vitro test results remains unclear and needs to be supported by further investigations to evaluate the impact of gargling with PVP-I in real-life and clinical settings, although for ethical reasons, clinical studies involving highly infective and dangerous pathogens may not be feasible. Furthermore, our testing was limited to a few key respiratory microorganisms. We selected Streptococcus pneumoniae as the main cause of communityacquired pneumonia and meningitis and Klebsiella pneumoniae because, although not a common cause of respiratory tract infections, it is an emerging cause of multidrug-resistant nosocomial infection. In addition, these species represent both gram-positive and -negative bacteria. Although our study did not include other common bacterial pathogens causing pneumonia such as Staphylococcus aureus, Pseudomonas aeruginosa, Haemophilus influenzae and Acinetobacter baumannii, the efficacy of PVP-I against these pathogens has already been demonstrated in previous studies $[16,18,32,33,41,46]$.

\section{CONCLUSION}

In conclusion, our study results, taken together with (1) recommendations for gargling with antiseptic mouthwash for the control of oral and respiratory tract infections, (2) the rapid bactericidal and virucidal efficacy of povidoneiodine, including PVP-I gargle/mouthwash, against pathogens causing oral and respiratory tract infections observed in other in vitro and in vivo studies and (3) the established safety profile of PVP-I from over 60 years of use, provide a strong rationale for the use of PVP-I oral solution for protective oropharyngeal hygiene management for individuals at high risk of exposure to oral and respiratory pathogens.

\section{ACKNOWLEDGEMENTS}

Funding. Sponsorship for both studies and article processing charges was funded by Mundipharma Research GmbH \& Co. KG (MRG). All authors had full access to all of the data in this study and take complete responsibility for the integrity of the data and accuracy of the data analysis.

Editorial Assistance. Editorial assistance in the preparation of this article was provided by Karen Mower of Scientific Editorial and funded by MRG.

Authorship. All named authors meet the International Committee of Medical Journal Editors (ICMJE) criteria for authorship for this article, take responsibility for the integrity of the work as a whole and have given their approval for this version to be published.

Prior Presentation. This work was presented at the 32nd Annual Meeting of the Japanese Society for Infection Prevention and Control, Japan, 24-25 February 2017.

Disclosures. Hygiene Nord GmbH and Laboratory Enders performed the studies on behalf of the sponsor, MRG. Maren Eggers was paid travel expenses and an honorarium by Mundipharma Pte Ltd. Torsten Koburger-Janssen is an employee of Hygiene Nord GmbH. Markus Eickmann has nothing to disclose. Juergen Zorn is an employee of MRG.

Compliance with Ethics Guidelines. This article does not contain any studies with human participants or animals performed by any of the authors. 
Open Access. This article is distributed under the terms of the Creative Commons Attribution-NonCommercial 4.0 International License (http://creativecommons.org/licenses/ by-nc/4.0/), which permits any noncommercial use, distribution, and reproduction in any medium, provided you give appropriate credit to the original author(s) and the source, provide a link to the Creative Commons license, and indicate if changes were made.

\section{REFERENCES}

1. World Health Organization. Antibiotic resistance fact sheet. 2016. http://www.who.int/mediacentre/ factsheets/antibiotic-resistance/en/. Accessed Mar 2018.

2. Centers for Disease Control and Prevention. Antibiotic resistance threats in the United States. 2013. https://www.cdc.gov/drugresistance/threatreport-2013/. Accessed Mar 2018.

3. World Health Organization. Resistant pneumococcal infections; the burden of disease and challenges in monitoring and controlling antimicrobial resistance. 2001. http://www.who.int/drugresistance/ technicalguidance/en/resistantinfection.pdf. Accessed Mar 2018.

4. World Health Organization. Influenza (seasonal) fact sheet. 2016. http://www.who.int/mediacentre/ factsheets/fs211/en/. Accessed Mar 2018.

5. World Health Organization. Frequently asked questions on Middle East respiratory syndrome coronavirus (MERS-CoV). 2015. http://www.who.int/csr/ disease/coronavirus_infections/faq/en/. Accessed Mar 2018.

6. Centers for Disease Control and Prevention. SARS basics fact sheet. 2004. https://www.cdc.gov/sars/ about/fs-sars.html. Accessed Mar 2018.

7. Berry M, Gamieldien J, Fielding BC. Identification of new respiratory viruses in the new millennium. Viruses. 2015;7:996-1019.

8. Hsieh YH. 2015 Middle East respiratory syndrome coronavirus (MERS-CoV) nosocomial outbreak in South Korea: insights from modeling. PeerJ. 2015;3:e1505. https://doi.org/10.7717/peerj.1505.

9. World Health Organization. WHO guidelines on hand hygiene in health care. 2009. http://www.who. int/gpsc/5may/tools/9789241597906/en/. Accessed Mar 2018.

10. Boyce JM, Pittet D, Healthcare Infection Control Practices Advisory Committee, HICPAC/SHEA/ APIC/IDSA Hand Hygiene Task Force. Guideline for hand hygiene in health-care settings. Recommendations of the Healthcare Infection Control Practices Advisory Committee and the HICPAC/SHEA/ APIC/IDSA Hand Hygiene Task Force. Society for Healthcare Epidemiology of America/Association for Professionals in Infection Control/Infectious Diseases Society of America. MMWR Recomm Rep. 2002;51:1-45.

11. Gralton J, Tovey ER, McLaws ML, Rawlinson WD. Respiratory virus RNA is detectable in airborne and droplet particles. J Med Virol. 2013;85:2151-9.

12. World Health Organization. Consensus document on the epidemiology of severe acute respiratory syndrome (SARS). 2003. http://www.who.int/csr/ sars/en/WHOconsensus.pdf. Accessed Mar 2018.

13. World Health Organization. Infection prevention and control during health care for probable or confirmed cases of novel coronavirus (nCoV) infection: interim guidance. 2013. http://www.who.int/csr/ disease/coronavirus_infections/ipc-mers-cov/en/. Accessed Mar 2018.

14. Kitamura T, Satomura K, Kawamura T, Great Cold Investigators-I, et al. Can we prevent influenza-like illnesses by gargling? Intern Med. 2007;46:1623-4.

15. Sneader W. Drug discovery: a history. New York: Wiley; 2005. p. 68.

16. McLure AR, Gordon J. In-vitro evaluation of povidone-iodine and chlorhexidine against methicillinresistant Staphylococcus aureus. J Hosp Infect. 1992;21:291-9.

17. Traoré O, Fayard SF, Laveran H. An in vitro evaluation of the activity of povidone-iodine against nosocomial bacterial strains. $\mathrm{J}$ Hosp Infect. 1996;34:217-22.

18. Shimizu M, Okuzumi K, Yoneyama A, et al. In vitro antiseptic susceptibility of clinical isolates from nosocomial infections. Dermatology. 2002;204(Suppl 1):21-7.

19. Gorman SP, Scott EM, Hutchinson EP. Effects of aqueous and alcoholic povidone-iodine on spores of Bacillus subtilis. J Appl Bacteriol. 1985;59:99-105.

20. Rikimaru T, Kondo M, Kondo S, Oizumi K. Bactericidal activities of povidone-iodine against $M y$ cobacterium. Dermatology. 1997;195(Suppl 2):104-6. 
21. Wutzler P, Sauerbrei A, Klöcking R, Brögmann B, Reimer K. Virucidal activity and cytotoxicity of the liposomal formulation of povidone-iodine. Antiviral Res. 2002;54:89-97.

22. Kawana R, Kitamura T, Nakagomi O, et al. Inactivation of human viruses by povidone-iodine in comparison with other antiseptics. Dermatology. 1997;195(Suppl 2):29-35.

23. Kariwa H, Fujii N, Takashima I. Inactivation of SARS coronavirus by means of povidone-iodine, physical conditions and chemical reagents. Dermatology. 2006;212(Suppl 1):119-23.

24. Eggers M, Eickmann M, Kowalski K, Zorn J, Reimer K. Povidone-iodine hand wash and hand rub products demonstrated excellent in vitro virucidal efficacy against Ebola virus and modified vaccinia virus Ankara, the new European test virus for enveloped viruses. BMC Infect Dis. 2015;15:375.

25. Eggers M, Eickmann M, Zorn J. Rapid and effective virucidal activity of povidone-iodine products against Middle East respiratory syndrome coronavirus (MERS-CoV) and modified vaccinia virus ankara (MVA). Infect Dis Ther. 2015;4:491-501.

26. Committee for the Japanese Respiratory Society Guidelines in Management of Respiratory. Prevention of hospital-acquired pneumonia (strategies for prevention of hospital-acquired infections). Respirology. 2004;9:S48-50.

27. EN 13727:2012 + A2@2015. Chemical disinfectants and antiseptics. Quantitative suspension test for the evaluation of bactericidal activity in the medical area. Test method and requirements (Phase 2/Step 1). 2015 .

28. EN 14476:2013/FprA1:2015. Chemical disinfectants and antiseptics. Quantitative suspension test for the evaluation of virucidal activity in the medical area. Test method and requirements (Phase 2/Step 1). 2015.

29. ISODINE $^{\circledR}$ Gargle $\mathrm{P}$ [package insert]. Shiongi Healthcare Co., Ltd, 2017.

30. Spearman C. The method of 'right and wrong cases' ('constant stimuli') without Gauss's formulae. Br J Psychol. 1908;2:227-42.

31. Kärber G. Beitrag zur Kollektiven Behandlung Pharmakologischer Reihenversuche [article in German]. Arch Exp Path Pharm. 1931;162:480-7.

32. Yoneyama A, Shimizu M, Tabata M, Yashiro J, Takata $T$, Hikida M. In vitro short-time killing activity of povidone-iodine (Isodine Gargle) in the presence of oral organic matter. Dermatology. 2006;212(Suppl 1):103-8.
33. Shiraishi T, Nakagawa Y. Evaluation of the bactericidal activity of povidone-iodine and commercially available gargle preparations. Dermatology. 2002;204(Suppl 1):37-41.

34. Ito $\mathrm{H}$, Ito $\mathrm{T}$, Hikida $\mathrm{M}$, et al. Outbreak of highly pathogenic avian influenza in Japan and ant-influenza virus activity of povidone-iodine products. Dermatology. 2006;212(Suppl 1):115-8.

35. Sriwilaijaroen $\mathrm{N}$, Wilairat $\mathrm{P}$, Hiramatsu $\mathrm{H}$, et al. Mechanisms of the action of povidone-iodine against human and avian influenza A viruses: its effects on hemagglutination and sialidase activities. Virol J. 2009;6:124. https://doi.org/10.1186/1743422X-6-124.

36. Steinmann J, Paulmann D, Becker B, Bischoff B, Steinmann E, Steinmann J. Comparison of virucidal activity of alcohol-based hand sanitizers versus antimicrobial hand soaps in vitro and in vivo. J Hosp Infect. 2012;82:277-80.

37. Sauerbrei A, Wutzler P. Virucidal efficacy of povidone-iodine-containing disinfectants. Lett Appl Microbiol. 2010;51:158-63.

38. Gottardi W. Iodine and iodine compounds. In: Block SS, editor. Disinfection, sterilization and preservation. Philadelphia: Lea \& Febiger; 1991. p. 152-66.

39. Kanagalingam J, Feliciano R, Hah JH, Labib H, Le TA, Lin JC. Practical use of povidone-iodine antiseptic in the maintenance of oral health and in the prevention and treatment of common oropharyngeal infections. Int $\mathrm{J}$ Clin Pract. 2015;69(11):1247-56.

40. Japan Ministry of Health, Labour and Welfare. Pandemic influenza preparedness action plan of the Japanese Government. 2007. http://www.mhlw.go. jp/english/topics/influenza/dl/pandemic02.pdf. Accessed Mar 2018.

41. Nagatake T, Ahmed K, Oishi K. Prevention of respiratory infections by povidone-iodine gargle. Dermatology. 2002;204(Suppl 1):32-6.

42. Satomura K, Kitamure T, Kawamura T, Great Cold Investigators-I, et al. Prevention of upper respiratory tract infections by gargling: a randomized trial. Am J Prev Med. 2005;29:302-7.

43. Okuda M, Kaneko Y, Ichinohe T, Ishihara K, Okuda $\mathrm{K}$. Reduction of potential respiratory pathogens by oral hygienic treatment in patients undergoing endotracheal anesthesia. J Anesth. 2003;17:84-91.

44. Madan PD, Sequeira PS, Shenoy K, Shetty J. The effect of three mouthwashes on radiation-induced oral mucositis in patients with head and neck 
malignancies: a randomized control trial. J Cancer Res Ther. 2008;4:3-8.

45. Rahn R, Adamietz IA, Boettcher HD, Schaefer V, Reimer K, Fleischer W. Povidone-iodine to prevent mucositis in patients during antineoplastic radiochemotherapy. Dermatology. 1997;195(Suppl 2):57-61.
46. Lanjri S, Uwingabiye J, Frikh $\mathrm{M}$, et al. In vitro evaluation of the susceptibility of Acinetobacter baumannii isolates to antiseptics and disinfectants: comparison between clinical and environmental isolates. Antimicrob Resist Infect Control. 2017;6:36. 